February 2005 • NREL/CP-520-37457

\title{
Effective Interfaces in Silicon Heterojunction Solar Cells
}

T.H. Wang, E. Iwaniczko, M.R. Page, D.H. Levi, Y. Yan, H.M. Branz, and Q. Wang

National Renewable Energy Laboratory

V. Yelundur and A. Rohatgi

Georgia Institute of Technology

Prepared for the $31^{\text {st }}$ IEEE Photovoltaics Specialists Conference and Exhibition

Lake Buena Vista, Florida

January 3-7, 2005
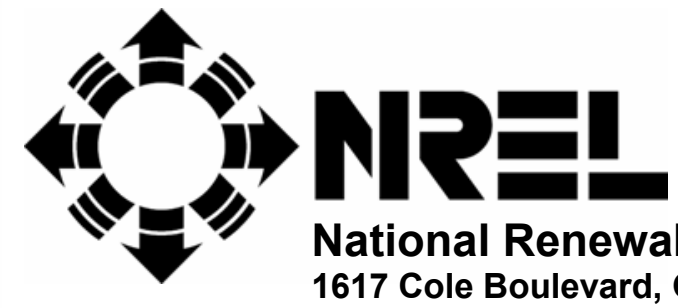

National Renewable Energy Laboratory

1617 Cole Boulevard, Golden, Colorado 80401-3393

303-275-3000 • www.nrel.gov

Operated for the U.S. Department of Energy

Office of Energy Efficiency and Renewable Energy

by Midwest Research Institute $\bullet$ Battelle

Contract No. DE-AC36-99-G010337 


\section{NOTICE}

The submitted manuscript has been offered by an employee of the Midwest Research Institute (MRI), a contractor of the US Government under Contract No. DE-AC36-99G010337. Accordingly, the US Government and MRI retain a nonexclusive royalty-free license to publish or reproduce the published form of this contribution, or allow others to do so, for US Government purposes.

This report was prepared as an account of work sponsored by an agency of the United States government. Neither the United States government nor any agency thereof, nor any of their employees, makes any warranty, express or implied, or assumes any legal liability or responsibility for the accuracy, completeness, or usefulness of any information, apparatus, product, or process disclosed, or represents that its use would not infringe privately owned rights. Reference herein to any specific commercial product, process, or service by trade name, trademark, manufacturer, or otherwise does not necessarily constitute or imply its endorsement, recommendation, or favoring by the United States government or any agency thereof. The views and opinions of authors expressed herein do not necessarily state or reflect those of the United States government or any agency thereof.

Available electronically at http://www.osti.gov/bridge

Available for a processing fee to U.S. Department of Energy and its contractors, in paper, from:

U.S. Department of Energy

Office of Scientific and Technical Information

P.O. Box 62

Oak Ridge, TN 37831-0062

phone: 865.576 .8401

fax: 865.576.5728

email: mailto:reports@adonis.osti.gov

Available for sale to the public, in paper, from:

U.S. Department of Commerce

National Technical Information Service

5285 Port Royal Road

Springfield, VA 22161

phone: 800.553 .6847

fax: 703.605.6900

email: orders@ntis.fedworld.gov

online ordering: http://www.ntis.gov/ordering.htm 


\title{
Effective Interfaces in Silicon Heterojunction Solar Cells
}

\author{
T.H. Wang, ${ }^{1}$ E. Iwaniczko, ${ }^{1}$ M.R. Page,${ }^{1}$ D.H. Levi, ${ }^{1}$ Y. Yan, ${ }^{1}$ \\ V. Yelundur, ${ }^{2}$ H.M. Branz, ${ }^{1}$ A. Rohatgi, ${ }^{2}$ and Q. Wang, \\ ${ }^{1}$ National Renewable Energy Laboratory, 1617 Cole Blvd., Golden, CO 80401, USA \\ ${ }^{2}$ Georgia Institute of Technology, 777 Atlantic Dr., Atlanta, GA 30332, USA
}

\begin{abstract}
Thin hydrogenated amorphous silicon (a-Si:H) layers deposited by hot-wire chemical vapor deposition (HWCVD) are investigated for use in silicon heterojunction (SHJ) solar cells on p-type crystalline silicon wafers. A requirement for excellent emitter quality is minimization of interface recombination. Best results necessitate immediate a-Si:H deposition and an abrupt and flat interface to the $\mathrm{c}-\mathrm{Si}$ substrate. We obtain a record planar $\mathrm{HJ}$ efficiency of $16.9 \%$ with a high $\mathrm{V}_{\text {oc }}$ of $652 \mathrm{mV}$ on p-type floatzone (FZ) silicon substrates with HWCVD a-Si:H(n) emitters and screen-printed Al-BSF contacts. $\mathrm{H}$ pretreatment by HWCVD is beneficial when limited to a very short period prior to emitter deposition.
\end{abstract}

\section{INTRODUCTION}

The a-Si:H/c-Si heterojunction solar cell is a good solution to the problems associated with high-temperature junction formation because a-Si:H deposited below $250^{\circ} \mathrm{C}$ can be used as the junction emitter, as the passivation layer, and as a full contact back-surface-field (BSF). The simple planar structure of the SHJ may also help control processing costs. Applied to the full device area of a ntype crystal silicon wafer as both the emitter and BSF contact, thin intrinsic and doped hydrogenated amorphous silicon (a-Si:H) double layers have demonstrated superior passivation capability as well as adequate carrier transport ability in high-efficiency silicon heterojunction solar cells in Sanyo's HIT structure [1]. The amorphous layers used in these n-type wafer-based HIT cells are deposited by plasma-enhanced chemical vapor deposition (PECVD). In principle, HWCVD could be superior to PECVD for silicon heterojunction solar cells because of higher deposition rates, reduced ion bombardment of the base wafer, and high densities of atomic hydrogen $(\mathrm{H})$ generation that may passivate the wafer interface region. However, obtaining high performance of heterojunction solar cells by using either PECVD or HWCVD, by groups other than Sanyo, has been a challenge. Efficiencies on the more commonly used and less expensive p-type silicon wafers have not been as high as on n-type wafers.

In this paper, we report our work on the silicon heterojunction solar cells based on p-type silicon wafers, using the HWCVD technique for the entire emitter deposition process. To eliminate complications of the backside heterojunctions [2], a standard Al-BSF is used, so that we may focus on understanding and optimizing the front interface passivation. We study the effects of various gas treatments and deposition conditions prior to and during HWCVD deposition of the a-Si:H emitter. Some of the findings from HWCVD should apply to a-Si:H emitter deposition in general, including PECVD.

Effective a-Si:H/c-Si interfaces that allow efficient transport of charge carriers with minimal recombination loss is a prerequisite for high-performance heterojunction solar cells, in which a thin $(\sim 5 \mathrm{~nm})$ intrinsic hydrogenated a-Si:H layer is generally interposed between the base wafer and the heavily doped emitter. This i-layer likely has a far lower density of defects and possibly a slightly larger energy gap than doped a-Si:H layers. If epitaxy extends through the i-layer, the defective interface will be contacted by the doped a-Si:H which is a less effective passivant than the intrinsic layer. Partial epitaxy, highly defective epitaxy, or a mixed phase i-layer can all cause detrimental high dark currents, because the a-Si:H/c-Si interface area or defect density will be large and the bandgap will be smaller. The additional dark-current path through inadequately passivated interface states in a heterojunction solar cell reduces the open-circuit voltage $\left(V_{o c}\right)$ to well below its potential value given by the higher total band bending. Therefore, we use $\mathrm{V}_{\mathrm{oc}}$ and the interface recombination velocity $(S)$ as the indicators of the effectiveness of an a-Si:H/c-Si heterointerface.

\section{EXPERIMENTAL}

The material evolution and phase change are closely monitored by real-time spectroscopic ellipsometry (RTSE) [3] with post-deposition data analysis, and samples are examined by high-resolution transmission electron microscopy (HRTEM). The interface recombination velocity $(S)$ is measured using a photoconductive decay lifetime measurement on an a-Si:H/c-Si/a-Si:H symmetric "sandwich". $\mathrm{V}_{\text {oc }}$ and other device parameters are characterized on a mesa-etched grid/ITO/a-Si:H/c-Si/Al solar cell structure. Surface cleaning, Si film deposition, front contact/ITO, Al-BSF fabrication, and characterizations, are carried out at NREL on Czochralski silicon (CZ-Si) wafers. An Al-BSF is screen-printed and belt-furnace fired at Georgia Tech on float-zoned (FZ) Si. Details of the NREL device fabrication process are described elsewhere [4]. Standard diffused junction FZ-Si solar cells used for comparison purposes are processed at Georgia Tech. 


\section{RESULTS AND DISCUSSIONS}

\section{Effect of deposition temperature}

The crystallinity of the deposited Si layer is found to be very sensitive to the deposition temperature and crystal orientation of the substrate. Crystallinity, in turn, affects an SHJ solar cell's performance dramatically. In one set of experiments, RTSE clearly indicates epitaxial growth up to $30 \mathrm{~nm}$ in thickness on a (100) substrate at $200^{\circ} \mathrm{C}$. On a (111) substrate at the same temperature, however, RTSE shows the film to be essentially a-Si:H as soon as the deposition starts. When the substrate temperature is higher, epitaxial growth can also be observed on (111) substrates. In Figure 1, through HRTEM imaging, one can see that epitaxy persists for $\sim 15 \mathrm{~nm}$ at $375^{\circ} \mathrm{C}$ on a (111) wafer, encompassing the i-layer $(5 \mathrm{~nm})$ and extending well into the n-layer. As a result, the open-circuit voltage $\left(V_{o c}\right)$ of this device is only $487 \mathrm{mV}$. When we lower the substrate temperature to $100^{\circ} \mathrm{C}$ for both the i- and n-layer deposition, abrupt amorphous-silicon growth is obtained, even on a (100) wafer, and a $V_{\text {oc }}$ greater than $620 \mathrm{mV}$ is obtained (Figure 2). Because of this tendency to grow epitaxial $\mathrm{Si}$ at higher HWCVD temperatures, $\mathrm{V}_{\text {oc }}$ decreases with increasing emitter deposition temperature. Figure 3 illustrates $V_{o c}$ as a function of the $\mathrm{i}$ - and $\mathrm{n}$-layer deposition temperatures (same for both layers) for 1.0 and $0.4 \Omega \cdot \mathrm{cm}(111)$ substrates. The best $V_{\text {oc }}$ and lowest $S$ are obtained at substrate temperatures of $100^{\circ}$ to $150^{\circ} \mathrm{C}$. When an epitaxial film grows through the intrinsic layer and into the doped layer, $\mathrm{V}_{\mathrm{oc}}$ is limited to $600 \mathrm{mV}$ or lower, depending on the a-Si/c-Si interface roughness and quality of the epitaxy [5]. With carefully chosen conditions to avoid epitaxial growth, we have achieved $V_{o c}$ values as high as $640 \mathrm{mV}$ on p-type CZ-Si.

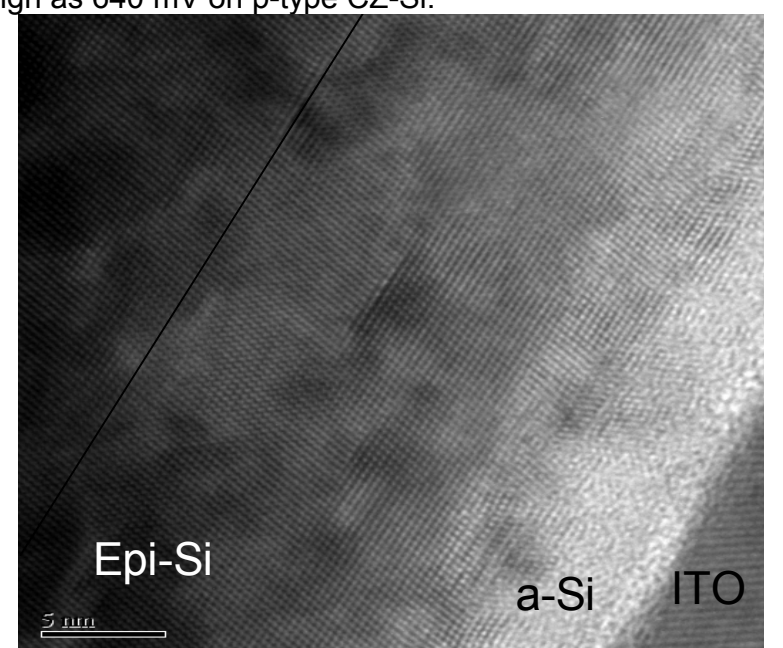

Fig. 1. Cross-sectional HRTEM image of Si deposition on a (111) wafer at $375^{\circ} \mathrm{C}$. Line shows the wafer surface.

The beneficial effect of an abrupt interface is shown in interface recombination velocity (S), also. Figure 4 shows $\mathrm{S}$ as a function of i-layer deposition temperature. For passivations the n-layer temperature was fixed at $300^{\circ} \mathrm{C}$ to activate the n-layer dopants. Reducing the i-layer temperature reduces $\mathrm{S}$ as $\mathrm{Si}$ epitaxy is suppressed.

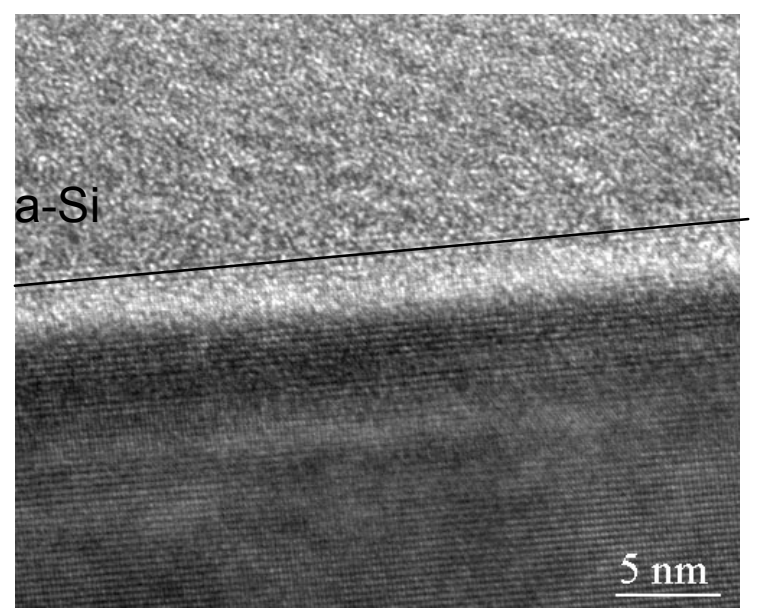

Fig. 2. Cross-sectional HRTEM image of Si deposition on a (100) wafer at $100^{\circ} \mathrm{C}$. Line shows the wafer surface.

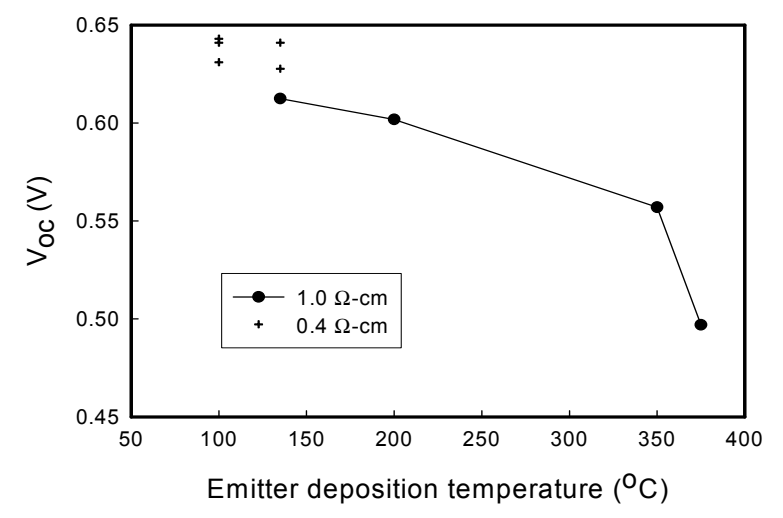

Fig. 3. $V_{o c}$ vs. the i- and n-layer temperature.

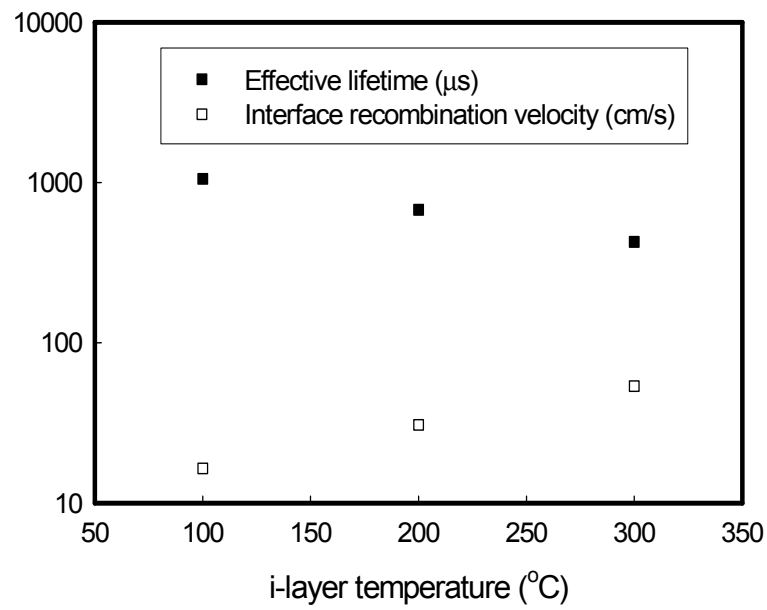

Fig. 4. $\mathrm{S}$ vs. i-layer temperature $(\mathrm{T})\left(\mathrm{n}\right.$-layer at $\left.\mathrm{T}=300^{\circ} \mathrm{C}\right)$.

\section{Effect of hot-wire pretreatment with $\mathrm{H}_{2}$}

With the expectation that exposure to atomic hydrogen before i- and n-layer deposition would help clean the wafer surface, remove residual oxide, and passivate surface defects, we tried exposing the wafer to cracked $\mathrm{H}_{2}$ gas before film growth. However, HRTEM indicated that 
prolonged pretreatment caused strain and defects in the Si wafer (Figure 5) and RTSE showed increased roughness at the interface. However, we find that a short atomic $\mathrm{H}$ pretreatment of the wafer $(\sim 10 \mathrm{sec})$ improved dark current and $\mathrm{V}_{\mathrm{oc}}$, as shown in Figures 6 and 7 . There has been some speculation that $\mathrm{H}$ pretreatment passivates $\mathrm{p}$-type dopants near the wafer surface [6]; this may be another reason that prolonged $\mathrm{H}$ exposure is detrimental to the solar cell performance.

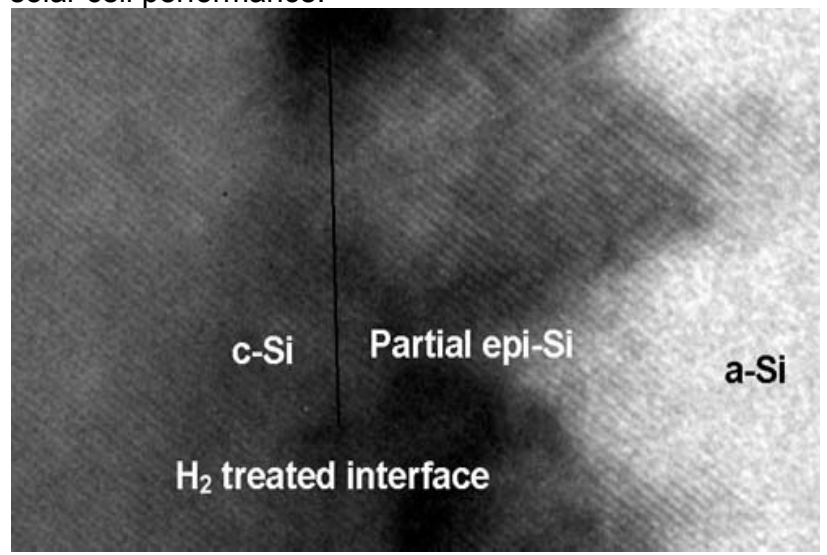

Fig. 5. Partial epitaxy and rough interface as a result of a 3-minute $\mathrm{H}$ pretreatment on (100) silicon.

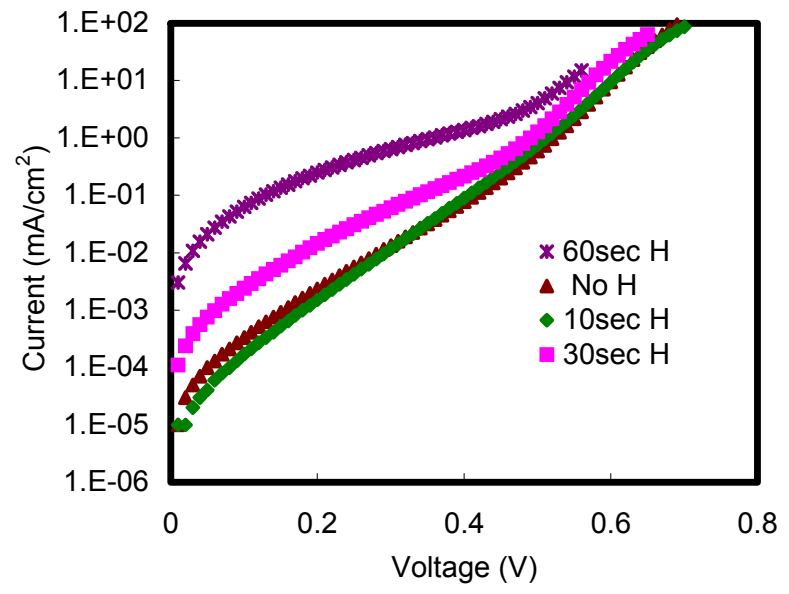

Fig. 6. $\mathrm{H}$ pretreatment vs. dark current.

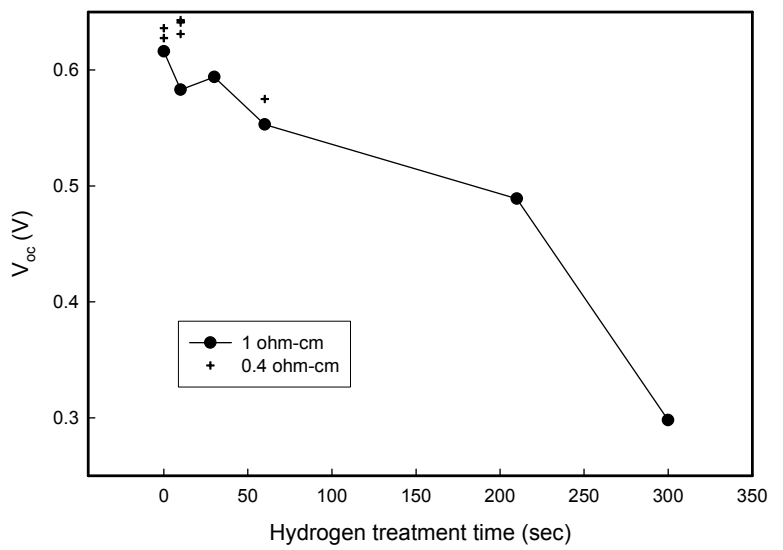

Fig. 7. Dependence of $\mathrm{V}_{\mathrm{oc}}$ on $\mathrm{H}$ pretreatment time.
Remarkably, a short atomic $\mathrm{H}$ pretreatment can replace the undoped a-Si:H layer in heterojunction devices on p-type wafers. Figure 8 shows that without $\mathrm{H}$ pretreatment, a thin intrinsic a-Si:H (i-layer) is critical to obtain good cell performance. On the other hand, Figure 9 indicates no clear advantage by using the i-layer in cells that are subjected to $\mathrm{H}$ pretreatment. However, these voltages are slightly lower (but better $\mathrm{J}_{\mathrm{sc}}$ ) due to the higher resistivity wafers used in the experiment.

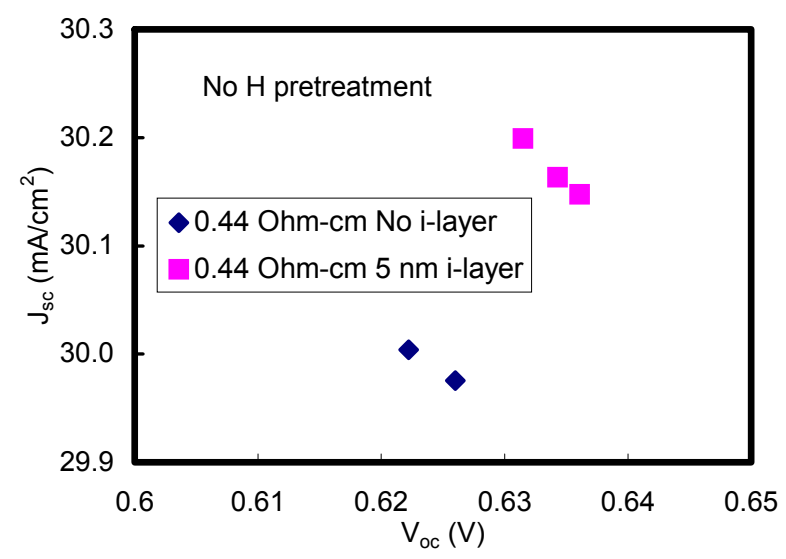

Fig. 8. Solar cell parameters with and without an undoped a-Si:H layer in heterojunction cells without $\mathrm{H}$ pretreatment.

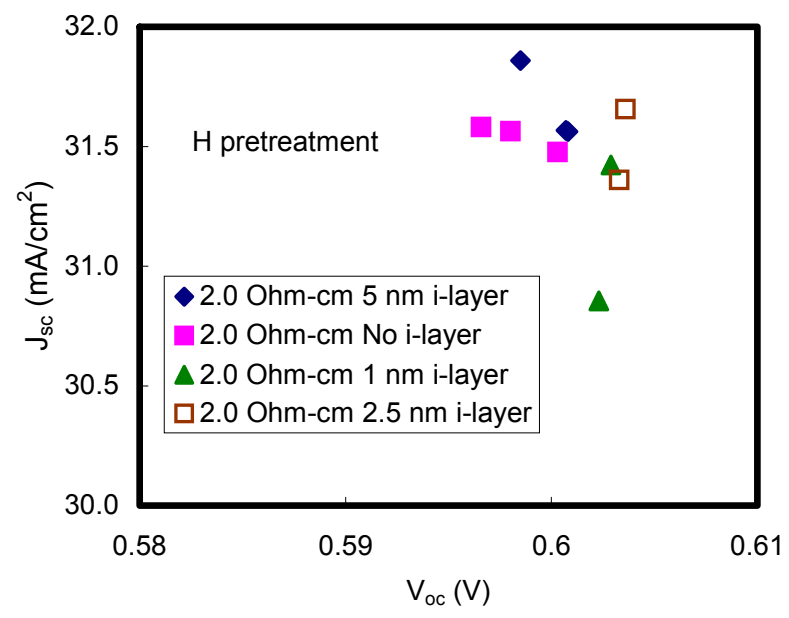

Fig. 9. Solar cell parameters with and without an undoped a-Si: $\mathrm{H}$ layer in heterojunction cells with a $10-\mathrm{sec} \mathrm{H}$ pretreatment.

\section{Heterojunction vs. diffused junction}

Using the same $F Z$ wafers with an identical screenprinted and belt-furnace fired Al-BSF, we fabricated both the heterojunction (HJ) and diffused-junction (DJ) solar cells. Our heterojunction solar cells employing the optimized a-Si:H emitter structure exhibit the highest reported efficiency $(16.9 \%)$, so far, for a flat-surface heterojuncton (Figure 10). The results listed in Table 1 show that $\mathrm{V}_{\mathrm{oc}}$ of the $\mathrm{HJ}$ devices is higher by about $15 \mathrm{mV}$ than that of the DJ devices for both the 1.0 and $0.5 \Omega \cdot \mathrm{cm}$ substrates. This again indicates the excellent interface passivation provided by the a-Si:H emitter. $\mathrm{J}_{\mathrm{sc}}$, however, 
is about $5 \%$ less than the DJ devices. Spectral response measurements (Figure 11) show that most of this current loss is due to poor blue response. Absorption measurements in our ITO and a-Si:H layers suggest that most of this loss is due to parasitic blue absorption in the a-Si:H emitter.

Table 1. 1-cm ${ }^{2}$ ITO/a-Si:H/c-Si/Al-BSF $\mathrm{HJ}$ solar cells in comparison with the standard $4-\mathrm{cm}^{2} \quad \mathrm{SiN}_{\mathrm{x}}: \mathrm{H} / \mathrm{c}-\mathrm{Si} / \mathrm{Al}-\mathrm{BSF}$ DJ solar cells (NREL independently verified)

\begin{tabular}{ccccccc}
\hline ID & emitter & $\begin{array}{c}\mathbf{V}_{\text {oc }} \\
(\mathbf{V})\end{array}$ & $\begin{array}{c}\mathbf{J}_{\text {sc }} \\
\left(\mathbf{m A} / \mathbf{c m}^{2}\right)\end{array}$ & $\begin{array}{c}\text { F.F. } \\
(\%)\end{array}$ & $\begin{array}{c}\text { Eff. } \\
(\%)\end{array}$ & $\begin{array}{c}\text { Substrate } \\
\text { flat FZ(p) }\end{array}$ \\
\hline $16 \mathrm{C}$ & $\mathrm{HJ}$ & 0.645 & 33.11 & 79.2 & 16.9 & $1.0 \Omega \cdot \mathrm{cm}$ \\
$65 \mathrm{C}$ & $\mathrm{HJ}$ & 0.652 & 32.16 & 80.5 & 16.9 & $0.5 \Omega \cdot \mathrm{cm}$ \\
$5-5$ & $\mathrm{DJ}$ & 0.630 & 34.90 & 78.1 & 17.2 & $1.0 \Omega \cdot \mathrm{cm}$ \\
$3-40$ & DJ & 0.636 & 33.82 & 78.9 & 17.0 & $0.5 \Omega \cdot \mathrm{cm}$ \\
\hline
\end{tabular}

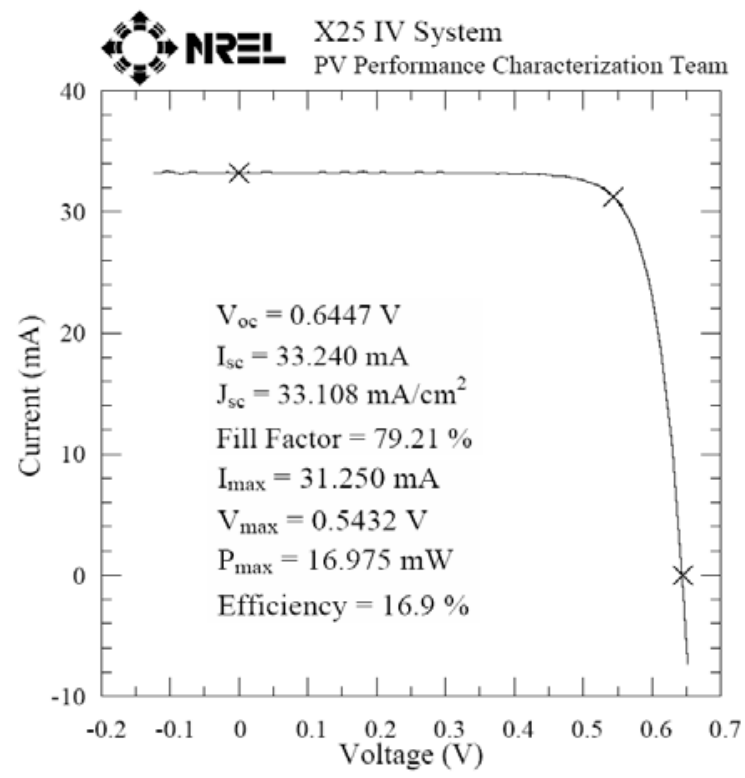

Fig. 10. I-V curve of solar cell 16C.

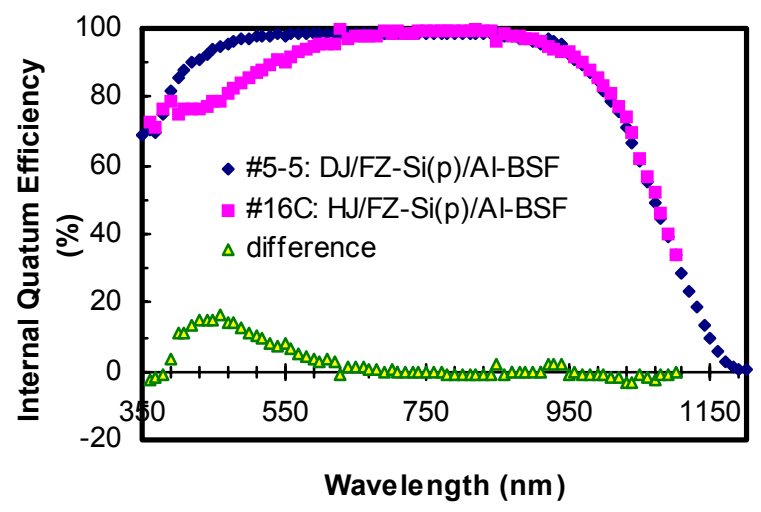

Fig. 11. Spectral responses of the DJ solar cell and the HJ solar cell, excluding the front reflective loss.

\section{SUMMARY}

Effective a-Si:H/c-Si heterointerfaces that allow efficient transport of charge carriers with minimal recombination loss can be obtained with immediate a-Si:H deposition and an abrupt and flat interface to the crystalline-silicon substrate. An abrupt and flat interface means that the a-Si:H/c-Si interface area is minimal, defect density stays low, and the bandgap on the amorphous side of the interface is large. This is accomplished by low-temperature deposition $\left(<150^{\circ} \mathrm{C}\right.$ for $(100)$ and $<200^{\circ} \mathrm{C}$ for (111)) of the thin silicon layers. A planar $\mathrm{HJ}$ record efficiency of $16.9 \%$ with a high $\mathrm{V}_{\text {oc }}$ of $652 \mathrm{mV}$ is achieved using screen-printed Al-BSF on untextured FZ-Si. Beneficial $\mathrm{H}$ pretreatment by HWCVD is limited to a very short period prior to emitter deposition. With adequate $\mathrm{H}$ pretreatment, an undoped a$\mathrm{Si}: \mathrm{H}$ thin layer does not seem to be necessary for the $\mathrm{p}$ type wafer-based HWCVD heterojunction solar cells. Higher $V_{\text {oc }}$ exhibited by heterojunction cells compared to similar diffused-junction cells indicates excellent interface passivation by the a-Si:H emitter. Minimization of parasitic absorption in the emitter, as well as front surface texturing, should increase $\mathrm{J}_{\mathrm{sc}}$ significantly.

\section{ACKNOWLEDGEMENTS}

The authors would like to thank Charles Teplin, Yueqin Xu, Scott Ward, Anna Duda, Richard Crandall, and Pauls Stradins for their valuable technical assistance and discussion. This work is supported by the U.S. DOE under Contract \#DE-AC36-99G010337

\section{REFERENCES}

[1] M. Taguchi, K. Kawamoto, S. Tsuge, T. Baba, H. Sakata, M. Morizane, K. Uchihashi, N. Nakamura, S. Kiyama, and O. Oota, Prog. Photovolt: Res. Appl. 8, 2000, pp. 503513.

[2] T.H. Wang, M.R. Page, E. Iwaniczko, D.H. Levi, Y. Yan, H.M. Branz, V. Yelundur, A. Rohatgi, G. Bunea, A.

Terao, and Q. Wang, $14^{\text {th }}$ Workshop on Crystalline Silicon Solar Cells \& Modules, Winter Park, CO, August 8-11, 2004; NREL/BK-520-36622, pp. 74-81.

[3] D.H. Levi, C.W. Teplin, E. Iwaniczko, R.K. Ahrenkiel, H.M. Branz, M.R. Page, Y. Yan, Q. Wang, and T.H. Wang, Materials Research Society Symposium Proceedings Vol. 808, 2004, pp. 239-242.

[4] M.R. Page, E. Iwaniczko, Q. Wang, D.H. Levi, Y. Yan, H.M. Branz, V. Yelundur, A. Rohatgi, and T.H. Wang, 14th Workshop on Crystalline Silicon Solar Cells and Modules, Winter Park, CO, August 8-11, 2004; NREL/BK520-36622, pp. 246-249.

[5] T.H. Wang, Q. Wang, E. Iwaniczko, M.R. Page, D.H. Levi, Y. Yan, C.W. Teplin, Y. Xu, X.Z. Wu, and H.M.

Branz, 19th European PV Solar Energy Conf., Paris, France, June 7-11, 2004. p.1296.

[6] F. Roca, J. Cárabe, A. Jäger-Waldau, 19th European PV Solar Energy Conf., Paris, France, June 7-11, 2004, p.1321. 


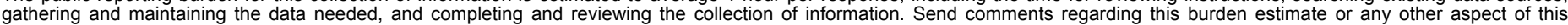

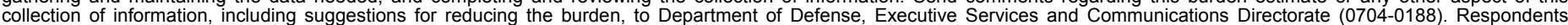

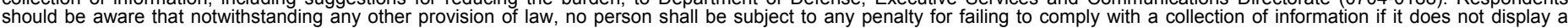

should be aware that notwithstanding

PLEASE DO NOT RETURN YOUR FORM TO THE ABOVE ORGANIZATION.

\begin{tabular}{l|ll} 
1. & REPORT DATE $(D D-M M-Y Y Y Y)$ \\
February 2005 & 2. & $\begin{array}{l}\text { REPORT TYPE } \\
\text { Conference Paper }\end{array}$ \\
\hline
\end{tabular}

4. TITLE AND SUBTITLE

Effective Interfaces in Silicon Heterojunction Solar Cells
3. DATES COVERED (From - To)

3-7 January 2005

5a. CONTRACT NUMBER

DE-AC36-99-GO10337

5b. GRANT NUMBER

5c. PROGRAM ELEMENT NUMBER

5d. PROJECT NUMBER

NREL/CP-520-37457

5e. TASK NUMBER

PVA54101

5f. WORK UNIT NUMBER
7. PERFORMING ORGANIZATION NAME(S) AND ADDRESS(ES)

National Renewable Energy Laboratory, 1617 Cole Blvd., Golden, CO

80401

Georgia Institute of Technology, 777 Atlantic Dr., Atlanta, GA 30332

9. SPONSORING/MONITORING AGENCY NAME(S) AND ADDRESS(ES)

\section{PERFORMING ORGANIZATION REPORT NUMBER}

NREL/CP-520-37457
10. SPONSOR/MONITOR'S ACRONYM(S) NREL

11. SPONSORING/MONITORING AGENCY REPORT NUMBER

12. DISTRIBUTION AVAILABILITY STATEMENT

National Technical Information Service

U.S. Department of Commerce

5285 Port Royal Road

Springfield, VA 22161

13. SUPPLEMENTARY NOTES

\section{ABSTRACT (Maximum 200 Words)}

Thin hydrogenated amorphous silicon (a-Si:H) layers deposited by hot-wire chemical vapor deposition (HWCVD) are investigated for use in silicon heterojunction (SHJ) solar cells on p-type crystalline silicon wafers. A requirement for excellent emitter quality is minimization of interface recombination. Best results necessitate immediate a-Si:H deposition and an abrupt and flat interface to the c-Si substrate. We obtain a record planar $\mathrm{HJ}$ efficiency of $16.9 \%$ with a high $\mathrm{V}_{\text {oc }}$ of $652 \mathrm{mV}$ on p-type float-zone (FZ) silicon substrates with HWCVD a-Si:H(n) emitters and screen-printed Al-BSF contacts. $\mathrm{H}$ pretreatment by HWCVD is beneficial when limited to a very short period prior to emitter deposition.

\section{SUBJECT TERMS}

PV; hydrogenated amorphous silicon (a-Si:H); hot-wire chemical vapor deposition (HWCVD); silicon heterojunction $(\mathrm{SHJ})$; solar cells; interface recombination; float-zone (FZ); emitter deposition;

\begin{tabular}{|c|c|c|c|c|}
\hline \multicolumn{3}{|c|}{ 16. SECURITY CLASSIFICATION OF: } & \multirow{2}{*}{$\begin{array}{l}\text { 17. LIMITATION } \\
\text { OF ABSTRACT } \\
\text { UL }\end{array}$} & \multirow{2}{*}{$\begin{array}{l}\text { 18. NUMBER } \\
\text { OF PAGES }\end{array}$} \\
\hline $\begin{array}{l}\text { a. REPORT } \\
\text { Unclassified }\end{array}$ & $\begin{array}{l}\text { b. ABSTRACT } \\
\text { Unclassified }\end{array}$ & $\begin{array}{l}\text { c. THIS PAGE } \\
\text { Unclassified }\end{array}$ & & \\
\hline
\end{tabular}

\begin{tabular}{l} 
19a. NAME OF RESPONSIBLE PERSON \\
\hline 19b. TELEPHONE NUMBER (Include area code) \\
\hline
\end{tabular}

